Gut, 1975, 16, 225-229

\title{
Complete identification of endocrine cells in the gastrointestinal tract using semithin-thin sections to identify motilin cells in human and animal intestine
}

\author{
JULIA M. POLAK, A. G. E. PEARSE, AND CATHERINE M. HEATH \\ From the Department of Histochemistry, Royal Postgraduate Medical School, London
}

SUMMARY The present (Wiesbaden) classification of gut endocrine cells relies mainly on ultrastructure and the results of silver impregnation. Correlation with hormone production requires parallel immunology but conventional immune cytochemistry is, in most cases, difficult or at present impossible.

The serial, semithin-thin-section technique offers an alternative, which provides absolute correlation between cell type and hormone production.

The successful use of the technique is illustrated here by localization of motilin in the enterochromaffin cells of the small intestine.

Identification of the endocrine polypeptide cells of the gut, at light microscopic level, is carried out by the techniques of immunocytochemistry, using either immunofluorescence (Coons, Leduc, and Connolly, 1955) or peroxidase labelling (Nakane and Pierce, $1966,1967)$. Cells so far identified in this way include those responsible for the production of gastrin, secretin, enteroglucagon, gastric inhibitory peptide (GIP), vasoactive intestinal peptide (VIP), and, most recently, motilin.

An entirely different classification of gut endocrine cells can be made by demonstrating their cytochemical characteristics, using methods other than immunological. The mainstay of this classification is the response of the cells to silver staining which results in a primary division into argentaffin (silver reducing) and argyrophil (silver absorbing). Subdivisions of the latter are made in terms of a number of eponymously named variations (Davenport, 1960; Hellerström and Hellman, 1960; Sevier and Munger, 1965; and Grimelius, 1968).

Identification of gut endocrine cells at the ultrastructural level is based mainly on the morphology of their storage granules, although other characteristics may be taken into account. Successive classifications of gut and pancreatic endocrine cells were made at Wiesbaden in 1969 (Creutzfeldt, Gregory, Grossman,

Received for publication 4 December 1974. and Pearse, 1970) and at Bologna in 1973 (Solcia, Pearse, Grube, Kobayashi, Bussolati, Creutzfeldt, and Gepts, 1973). They are known collectively by the former appellation and the individual cell types, indicated by capital letters, are: in the stomach, EC (enterochromaffin) A-like, D, D1, G, ECL (enterochromaffin-like); in the intestine, EC, EG (enteroglucagon) $\mathrm{D}, \mathrm{D}_{\mathbf{1}}, \mathrm{G}, \mathrm{S}, \mathrm{I}, \mathrm{K}$; in the pancreas, $\mathrm{B}, \mathrm{A}$, $\mathrm{D}, \mathrm{D}_{1}$.

While some of these initial letters are those of the presumptive hormone contained in the granules whose ultrastructure they signify (Gastrin, Secretin EnteroGlucagon) in the remaining cases they are either based on a former Greek nomenclature $(\beta, \alpha$, $\delta$ ) or invented de novo. The situation is clearly unsatisfactory and equally clearly resolution can come only by the establishment of complete identity between electron microscopic granule morphology and hormone content. When this is achieved secondary cytochemical characteristics fall into line. Silver methods form an essential link between light microscopic and electron microscopic appearances since they can successfully be applied to thin or semithin resin-embedded sections. Silver methods were first successfully applied at the ultrastructural level by Solcia, Vassallo, and Capella (1970).

In the general field of endocrinology the problem of identifying specific hormones with specific granule morphology has been approached by the use of 
standard techniques of immune electron cytochemistry. These involve the application of immunological reactions either to small tissue blocks before fixation and embedding or to thin, resin-embedded sections after the removal of resin. The first approach has fallen into disuse because of failure of the antibody to penetrate beyond the first layer of cells in a tissue block. Thin-section methods have been applied successfully in the case of pituitary endocrine cells (Nakane, 1971; Moriarty and Halmi, 1972; Parsons and Erlandsen, 1974) and claims have been made for the identification of gastrin in $G$ cells (Greider, Steinberg. and McGuigan, 1972). No other reports on gut hormone localization at EM level seem to have appeared.

We present here the successful use of an alternative method, an extension and amplification of that used by Bussolati and Canese (1972), to demonstrate the association of gastrin with the $G$ cells, for the complete identification of motilin cells in the small intestine. This method, which can be called the serial semithin-thin section technique, depends on the application, to successive (serial) sections of immunocytochemistry, conventional counterstained electron microscopy, and cytochemistry (silver techniques) respectively.

\section{Materials and Methods}

Small fragments of duodenal and jejunal mucosa, freshly removed, from man, pig, and dog, were fixed immediately for two hours at $4^{\circ}$ in one of the following fixatives: (1) methanol-free formaldehyde (MFF) as described by Polak, Bussolati, and Pearse (1971); (2) a $1 / 1$ mixture of MFF with $3 \%$ glutaraldehyde in $0.1 \mathrm{M}$ phosphate buffer at $\mathrm{pH} 7 \cdot 2$; (3) $2 \%$ watersoluble carbodiimide (CDI) according to the method of Polak, Kendall, Heath, and Pearse (1972); (4) $3 \%$ p-benzoquinone in $0.1 \mathrm{M}$ phosphate buffer at $\mathrm{pH} 7 \cdot 2$ (Pearse and Polak, 1974).

In each case the tissues were then rinsed in several changes of $0.1 \mathrm{M}$ phosphate buffer (7.2) containing $0.1 \mathrm{M}$ sucrose and then dehydrated in an ascending gradient of alcohols. Some blocks were then taken through propylene oxide and all were left overnight at $45^{\circ}$ in Araldite I (without accelerator). They were then embedded in Araldite II (containing BDMA accelerator) and polymerized at $45^{\circ}$ to avoid damaging the antigenic determinant sites by heat denaturation. Contact with osmium was avoided in all cases.

Sections were first cut at $1 \mu \mathrm{m}$ and stained with $1 \%$ toluidine blue in $3 \%$ sodium tetraborate in order to check the topography and orientation of the block. When a suitable area was found, the following sections were cut:
1 A single semithin section at $1 \mu \mathrm{m}$, placed on a drop of $10 \%$ acetone on a glass slide, dried down for a maximum of 10 minutes on a $45^{\circ}$ hot plate, and left overnight at $37^{\circ}$.

2 Several serial thin $(60 \mathrm{~nm})$ sections, placed (a) on a 200-mesh copper grid for conventional electron microscopy; and (b) on a 200-mesh nickel grid, for silver impregnation followed by electron microscopy.

3 A further serial semithin $(1 \mu \mathrm{m})$ section, placed in a drop of $10 \%$ acetone on a glass slide and dried on the hot plate. This section is used for light microscopic silver impregnation.

\section{IMMUNOFLUORESCENCE}

The first semithin section was treated as follows: the araldite was removed with saturated alcoholic sodium hydroxide and the section was then rehydrated through a descending gradient of alcohols, to distilled water and then to phosphate-buffered saline (PBS). An indirect (sandwich) technique was then applied using antibody against pure porcine motilin (Pearse, Polak, Bloom, Adams, Dryburgh, and Brown, 1974). Sections which had been fixed in MFF or MFF/glutaraldehyde were viewed microscopically, before immunostaining, to check for formaldehydeinduced fluorescence (FIF).

Fluorescence preparations were examined in a Leitz Orthoplan microscope fitted with HBO 100 and XBO 75 lamps and a Ploem illuminator. The FITC-labelled sections were excited at $490 \mathrm{~nm}$ using two KP 490 interference filters and a TK 510 dichroic mirror. A K 515 barrier filter was employed and photomicrographs were taken on Ilford FP4 film, at high and low magnifications. Two prints were then prepared from each negative (a) emulsion side up and (b) emulsion side down. This was done to avoid confusion with reversal of micrographs at EM level.

\section{ELECTRON MICROSCOPY}

Sections on copper grids were stained with $15 \%$ uranyl acetate in methanol and then with lead citrate. They were viewed in a Corinth 275 electron microscope, initially in the 'scan' mode. The image obtained was compared with photomicrographs of the relevant cells in immunohistochemical preparations. We used histological landmarks in order to match the two views, such as blood vessels, gland lumina, mucous cells, etc. Once the correct area had been verified electron micrographs of each relevant endocrine cell were taken at higher magnification.

Sections on the nickel grids were stained by the Masson-Fontana reaction as follows:

Concentrated ammonia (spG 0.88 ) was added dropwise to $10 \%$ aqueous silver nitrate until the precipitate was redissolved. Fresh silver nitrate was then added, to the point of persistent opalescence. 
The solution was then filtered. The grids were - floated, sectionside down, on a drop of this solution, and placed in a closed container for 30 minutes at $60^{\circ}$. They were then rinsed in distilled water and fixed in $1 \%$ sodium thiosulphate for one minute.

These grids were viewed in the Corinth 275 electron microscope as noted above.

The semithin sections for light microscopic cytochemistry were treated with the Masson-Fontana reagent at $60^{\circ}$, without removal of the resin, and after five minutes' incubation the reaction was constantly checked under the microscope. When staining was judged adequate the sections were briefly fixed (one min) in sodium thiosulphate before dehydration and mounting in DPX. Photomicrographs were taken on Ilford Pan F film.

\section{Results}

From a total of 128 blocks, prepared in different ways from material from the three species, we were able to use $28(22 \%)$. With all the others the immunofluorescence reaction for motilin was negative when carried out on semithin sections. This low percentage of useful material can be attributed to a number of possible factors: (1) there may have been damage at an unacceptable level to the antigenic determinant site of motilin in the endocrine cells; (2) because of the scattered and occasionally sparse location of reactive endocrine cells in the mucosa there may have been, in any particular block, too few cells for positive identification.

From the 28 blocks in which we obtained positive motilin immunofluorescence only 12 could be used for correlation between light and electron microscopy. There were several reasons for this: (1) positively reacting cells came under the grid bars (perhaps avoidable by using slot grids with formvar film). (2) Our thin sections were not always absolutely serial. It was essential, therefore, to adhere closely to the proposed sequence: (a) semithin section for immunofluorescence; (b) serial thin section for uranyl acetate-lead citrate staining and electron microscopy; (c) serial thin section for silver impregnation; $(d)$ serial semithin section for silver impregnation; (3) poor preservation of ultrastructure. Bifunctional cross-linking reagents other than the two aldehydes, while superior for preservation of antigens, often preserved the ultra-structure poorly.

It must be emphasized that our high overall failure rate was entirely technical in nature. We obtained positive motilin immunofluorescence in all regions of small intestine which we tested, and in all three species.

The morphological characteristics and distribution of immunofluorescent motilin cells have already been
All sections are from an Araldite-embedded block of dog. jejunum (third part).

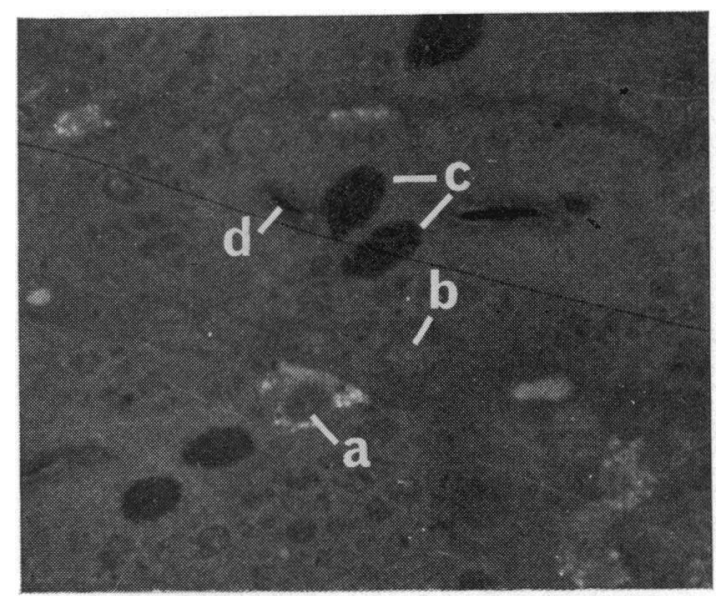

Fig 1 Serial section no. 1, the first (semithin) section. Indirect immunofluorescence for motilin. Shows (a) a single triangular motilin cell, (b) a blood vessel containing cells, (c) two mucous cells, and (d) the lumen of the gland which contains them. $\times 800$.

described by Pearse et al (1974). The illustrations (figs 1-5) are a representative set chosen from a number of essentially similar sets, in order to illustrate the rationale and type of result obtainable with the semithin-thin technique.

Figure 1 shows an overall view of one selected region from a block of dog jejunum containing an immunofluorescent motilin cell (a). Also marked are a cell in a blood vessel (b), two mucous cells (c), and (d) a gland lumen. The conventional electron micrograph (fig 2 ) shows precisely the same features except that the motilin cell can now be seen, and better still at higher magnification as in fig 3 , to contain electron-dense, non-spherical granules of the type associated with EC cells. When the MassonFontana silver method is applied (fig 4) the motilin cell granules are found to be argentaffin. This is better seen at higher magnification (inset). These results confirm the identity of the motilin cell as an EC cell and, finally, we obtain further confirmation in the light microscopic Masson-Fontana preparation (fig 5) where the storage granules of the motilin cell seen first in fig 1 are seen to be argentaffin.

\section{Discussion}

The 22-amino acid residue peptide motilin was first purified from a side fraction obtained during 


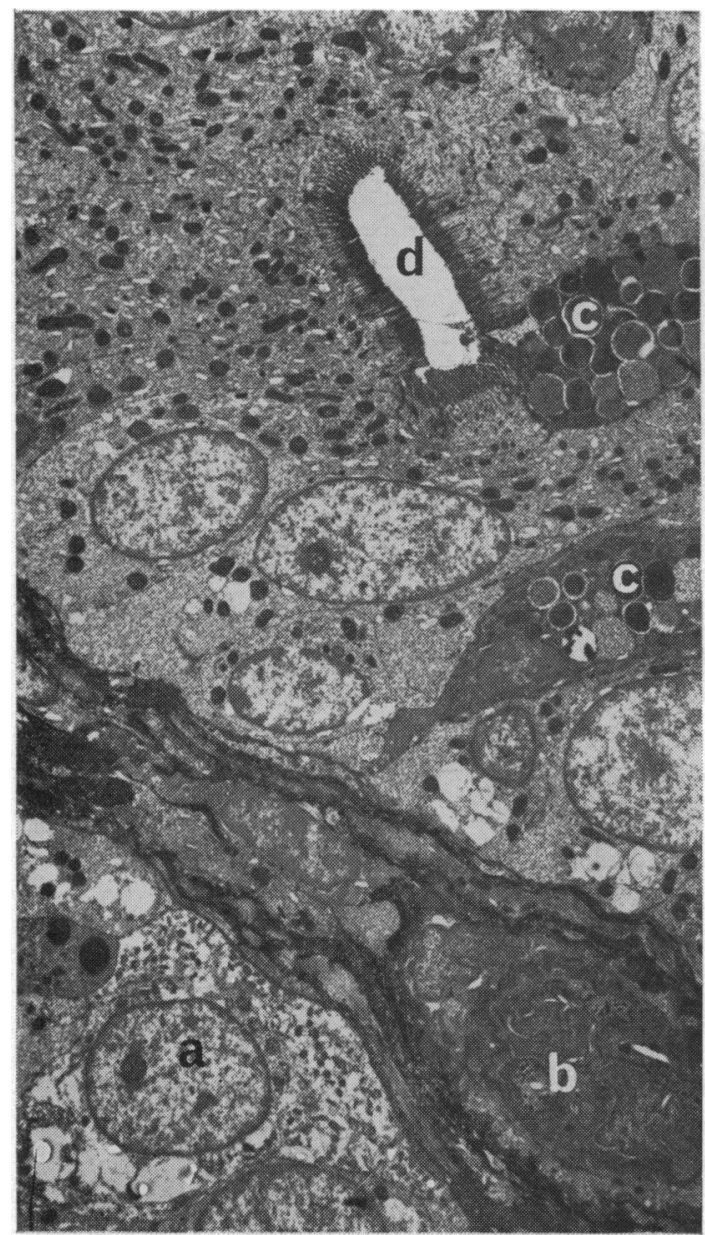

Fig 2

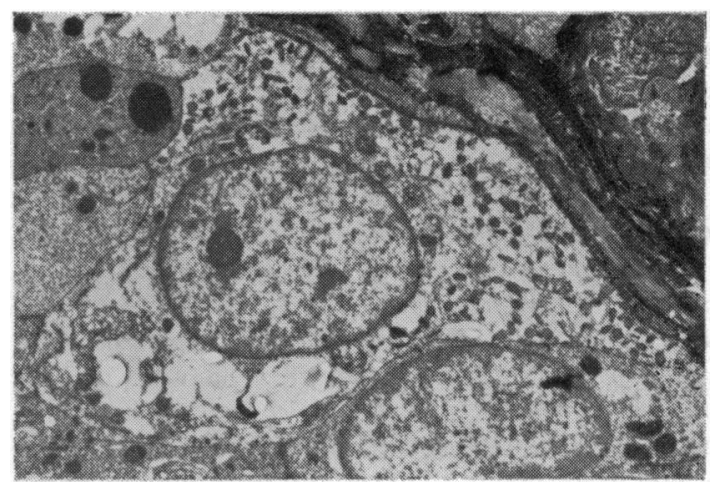

Fig 3

Fig 2 Serial section no. 2, the second (thin) section. Stained with uranyl acetate and lead citrate for comparison with figure 1. Letters refer as in the latter. $\times 3000$.

Fig 3 Serial section no. 2. This enlarged view shows (a) the endocrine (motilin) cell. It can now be seen that. its electron-opaque granules are of the type characteristic of enterochromaffin cells. $\times 5500$.

Fig 4 Serial section no. 3, the third (thin) section, stained by the Masson-Fontana method, shows the argentaffinity of its spherical and non-spherical granules. (Inset, an enlarged view, $\times 50000$ of some of the granules containing a dense silver deposit). $\times 5500$.

Fig 5 Serial section no. 4, the fourth and final (semithin) section. Silver impregnation by the Masson-Fontana method. Shows a argentaffin granules in the same cell as in figs 1-4 and $\mathrm{b}$ the same blood vessel and contents. $\times 800$.

$\mathrm{a}=$ motilin cell, $\mathrm{b}=$ blood cells, $\mathrm{c}=$ mucous cell, $\mathrm{d}=$ lumen

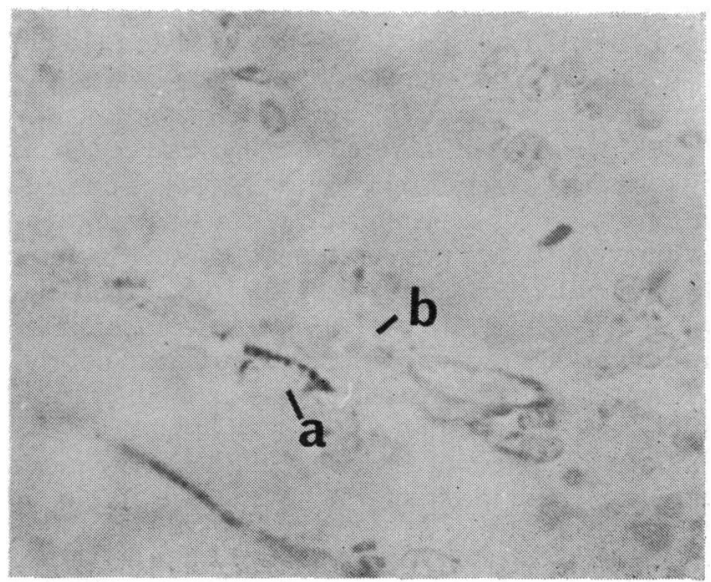

Fig 5

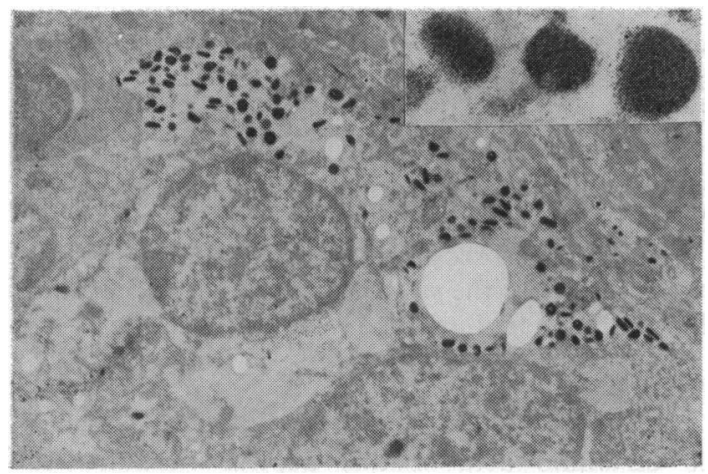

Fig 4 
the purification of secretin (Brown, Mutt, and Dryburgh, 1971) and its sequence was determined by Brown, Cook, and Dryburgh (1973). A norleucyl analogue has been synthesized (Wünsch, Brown, Deimer, Drees, Jaeger, Mussiol, Scharf, Stocker, Thamm, and Wendelberger, 1973). Its physiological role has not yet been established but it is known to stimulate gastric motility. Our studies reported here confirm completely the original report (Pearse et al, 1974) indicating that the source of motilin is the EC cell of the small intestine. This cell belongs to the APUD series (Pearse, 1966, 1968), as do the other gut endocrine cells.

Apart from the significance of this observation our results point clearly to the conclusion that, for an organ like the gut, with some 12 or 13 endocrine cell types scattered diffusely in the mucosa, the semithin-thin technique offers the best chance of firm correlation between ultrastructural morphology and immunocytochemistry.

It is not difficult in an organ like the thyroid, where a single cell type is responsible for a single peptide, calcitonin, to demonstrate this with a direct immune electron cytochemical technique (Kalina and Pearse, 1971). It is possible to achieve reasonable distinction between cell types, in a compact gland like the pituitary, by similar direct techniques (Nakane, 1971) even though the resulting ultrastructural morphology may be very poor indeed. It will be extremely difficult to identify an endocrine cell in the gut which has lost most of its components and to which an electron-dense immune deposit has been superadded.

We therefore consider that a semithin-thin technique is likely to prove optimal for researches into the endocrinology of the gut and that its furtherance can be achieved if a suitable (bifunctional) reagent or combination of reagents can be found which will provide an acceptable degree of ultrastructural preservation with the minimum degree of interference with the conformation of the determinant sites in various hormone antigens. We are continuing our researches in this direction.

We are grateful to Professor J. C. Brown for the gift of motilin and to Miss M. V. McCrossan for expert technical assistance. The work was carried out with the help of a grant from the Cancer Campaign.

\section{References}

Brown, J. C., Cook, M. A., and Dryburgh, J. R. (1973). Motilin, a gastric motor activity stimulating polypeptide: the complete amino acid sequence. Canad.J. Biochem., 51, 533-537.

Brown, J. C., Mutt, V., and Dryburgh, J. R. (1971). The further purification of motilin, a gastric motor activity stimulating polypeptide from the mucosa of the small intestine of hogs. Canad. J. Physiol. Pharmacol., 49, 399-405.

Bussolati, G., and Canese, M. G. (1972). Electron microscopical identification of the immunofluorescent gastrin cells in the cat pyloric mucosa. Histochemie, 29, 198-206.

Coons, A. H., Leduc, E. H., and Connolly, J. M. (1955). Studies on antibody production. I. A method for the histochemical demonstration of specific antibody and its application to a study of the hyperimmune rabbit.J. exp. Med., 102, 49-60.

Creutzfeldt, W., Gregory, R. A., Grossman, M. I., and Pearse, A. G. E. (1970). In Origin, Chemistry, Physiology and Pathophysiology of the Gastrointestinal Hormones. Proceedings of an International Symposium, Wiesbaden, 1969, p. 95. Schattauer, Stuttgart and New York.

Davenport, H. A. (1960). Histological and Histochemical Technics, p. 250. Saunders, Philadelphia and London.

Greider, M. H., Steinberg, V., and McGuigan, J. E. (1972). Electron microscopic identification of the gastrin cell of the human antral mucosa by means of immunocytochemistry. Gastroenterology, 63, 572-583.

Grimelius, L. (1968). A silver nitrate stain for $\alpha_{2}$ cells in human pancreatic islets. Acta Soc. Med. upsalian, 73, 243-270.

Hellerström, C., and Hellman, B. (1960). Some aspects of silver impregnation of the islets of Langerhans in the rat. Acta endocr. (Kbh.), 35, 518-532.

Kalina, M., and Pearse, A. G. E. (1971). Ultrastructural localization of calcitonin in C cells of dog thyroid: an immunocytochemical study. Histochemie, 26, 1-8.

Moriarty, G. C., and Halmi, N. S. (1972). Electron microscopic study of the adrenocorticotropin-producing cell with the use of unlabeled antibody and the soluble peroxidase-antiperoxidase complex.J. Histochem. Cytochem., 20, 590-603.

Nakane, P. K. (1971). Application of peroxidase-labelled antibodies to the intracellular localization of hormones. Acta endocr. (Kbh.), Suppl., 153, 190-204.

Nakane, P. K., and Pierce, G. B. (1966). Enzyme-labeled antibodies: Preparation and application for the localization of antigens. $J$. Histochem. Cytochem., 14, 929-931.

Nakane, P. K., and Pierce, B. G. (1967). Enzyme-labeled antibodies for the light and electron microscopic localization of tissue antigens. J. Cell Biol., 33, 307-318.

Parsons, J. A., and Erlandsen, S. L. (1974). Ultrastructural immunocytochemical localization of prolactin in rat anterior pituitary by use of the unlabeled antibody enzyme method.J. Histochem. Cytochem., 22, 340-351.

Pearse, A. G. E. (1966). 5-Hydroxytryptophan uptake by dog thyroid $\mathrm{C}$ cells and its possible significance in polypeptide hormone production. Nature (Lond.), 211, 598-600.

Pearse, A. G. E. (1968). Common cytochemical and ultrastructura characteristics of cells producing polypeptide hormones (The APUD series) and their relevance to thyroid and ultimobranchial C cells and calcitonin. Proc. roy. Soc. B., 170, 71-80.

Pearse, A. G. E., and Polak, J. M. (1974). Bifunctional reagents as vapour and liquid phase fixatives for immunohistochemistry. Micro 74. Proc. roy. micr. Soc., 9, 67.

Pearse, A. G. E., Polak, J. M., Bloom, S. R., Adams, C., Dryburgh, J. R., and Brown, J. C. (1974). Enterochromaffin cells of the mammalian small intestine as the source of Motilin. Virchows Arch. B. Cell Path., 16, 111-120.

Polak, J. M., Bussolati, G., and Pearse, A. G. E. (1971). Cytochemical, immunofluorescence and ultrastructural investigations on the antral G cells in hyperparathyroidism. Virchows Arch. B. Cell, Path. 9, 187-197.

Polak, J. M., Kendall, P. A., Heath, C. M., and Pearse, A. G. E. (1972). Carbodiimide fixation for microscopy and immunoelectron chemistry. Experientia (Basel), 28, 368-370.

Sevier, A. C., and Munger, B. L. (1965). A silvermethod for paraffin sections of neural tissue. J. Neuropath. exp. Neurol., 24, 130-135.

Solcia, E., Pearse, A. G. E., Grube, D., Kobayashi, S., Bussola, G., Creutzfeldt, W., and Gepts, W. (1973). Revised Wiesbaden classification of gut cells. Rendic. Gastroent., 5, 13-16.

Solcia, E., Vassallo, G., and Capella, C. (1970). Cytology and cytochemistry of hormone producing cells of the upper gastrointestinal tract.In Origin, Chemistry, Physiology and Pathophysiology. of the Gastrointestinal Hormones: Proceedings of an International Symposium, Wiesbaden, 1969, edited by W. Creutzfeltd et al., pp. 3-29. Schattauer, Stuttgart and New York.

Wünsch, E., Brown, J. C., Deimer, K. H., Drees, F., Jaeger, E., Mussiol, J., Scharf, H., Stocker, H., Thamm, P., and Wendelberger, G. (1973). Zur Synthbe von Norleucin-13-Motilin (vorlăufige. Mitteilung).Z. Naturforsch., 28, 235-240. 